\title{
Relexification scope and the limits of Full Transfer Full Access Hypothesis in Second Language Acquisition
}

Paulo Antonio Pinheiro Correa (UFF)

Recebido 15, jan. 2011/Aprovado 7, fev. 2011

\begin{abstract}
This paper on Second Language Acquisition analyzes the case of quedar(se), a pseudo-copular verb typical of the interlanguage system of Brazilians nonnative speakers of Spanish. It combines syntactic and semantic properties from its corresponding element in Brazilian Portuguese, the speakers L1, and phonological features from the Spanish supposed counterpart. This element maintains itself in interlanguage until its steady state and it is analyzed here as a case of relexification (LEFEBVRE, 1997), a universal process present in many language contact situations, among them, Second Language Acquisition.
\end{abstract}

Keywords: Second Language Acquisition, Language contact, Spanish. Relexification. 


\section{Introduction}

This paper discusses a case of relexification (MUYSKEN, 1981; LEFEBVRE, 1997) in nonnative Spanish spoken by Brazilians, concentrating on the expression of punctual change of state (henceforth COS) in this system.

L2 Spanish speaking Brazilians tend to Express COS in their interlanguage using adjectival passives, while in the target language COS is mainly expressed by verbal constructions, as in the examples below:

(1) Spanish: Ana se enojó con Juan por el retraso.

'Ana got angry at Juan for his delay.'

(2) Interlanguage: Ana se quedó enojada con Juan por el retraso

"Ana got angry at John for his delay."

Besides that, interlanguage exhibits another property that differentiates it further from the goal language: when using predicative constructions (adjectival passives) for expressing COS and change of property Brazilians tend to use a sole wild-card pseudo-copular verb (quedar(se) as in example [2]) instead of using one of the several case-specific options available in the goal language. This paper will address specifically the expression of COS in this interlanguage, regarding the use of quedar(se) as a case of relexification.

The study, based on Full Transfer Full Access Hypothesis (SCHWARTZ \& SPROUSE, 1994) shows that relexification, differently from Schwartz and Sprouse's hypothesis' predictions, applies until the individuals' interlanguages reach their steady state, revealing a permanent failure in the acquisition process of these constructions by Brazilians with a formal instruction in Spanish. This leads to consider the existence of circumstances where the predictions of that hypothesis on SLA do not apply. The situation analyzed here, involving typologically related languages such as Portuguese and Spanish, may be one of those.

The paper is divided as follows: the first section presents the theoretical underpinnings of this research. Next section discusses COS in the framework of lexical semantics and how this notion is expressed in Spanish. The last one presents interlanguage COS constructions and the discussion of the results.

\section{Theoretical underpinnings}

\subsection{Full Transfer Full Access and SLA}

Schwartz and Sprouse's (1994) Full Transfer Full Access Hypothesis (henceforth, FTFA) on interlanguage genesis and development, states that the way adult learners acquire a second language 
1 According to modern research on SLA, based on the Minimalist Program, besides parameters, other elements featured in the architecture of grammar, such as features, feature values or feature deployment could be transferred and conform the properties of initial state interlanguage. Whenever we say 'parameters' in this paper we mean all these properties. is a two-step process, full transfer, when interlanguage exhibits the properties of the learners' L1 and full access, when interlanguage gradually reset its parameters towards a convergence with the target language.

According to it, in the first step, full transfer the whole grammar (its parameters/formal features together with the corresponding values ${ }^{1}$ but the phonological matrices) is transferred to the individual's cognition thus forming the initial state interlanguage which combines these features with the L2 phonology features, forming a device that allows the individuals to begin to access and process the L2 input they are exposed to.

Nevertheless this is the first moment of the process, according to FTFA hypothesis. Some changes will eventually happen in this system as the amount of exposure to L2 data increases. Across interlanguage development it is expected that there will be plenty of moments where its properties will not be able to process L2 input data. These situations are the adequate triggers for IL restructuring. Whenever it happens, interlanguage parameters can - ideally - be reset, towards an ideal convergence with the target language, a process mediated by Universal Grammar. According to this, what allows the growth of the interlanguage are the mismatches between IL parameters/features/feature values/ feature deployment and the L2 input. The absence of such mismatches, tough, could have an inverse effect, not allowing the learner's system to grow.

\subsection{Relexification}

Lefebvre (1997), based on Muysken's (1981) definition of relexification defines it as a mental process creating lexical entries by copying lexical entries from a preexisting lexicon changing its phonological representations for ones derived from the other language. It is a generative, UG-based concept for explaining properties of creole languages and it is a semantic-driven process. According to this, as Couto (2002) observes, in a creole language resulting from a language contact situation exhibiting this process, some of its lexical entries will have semantic and syntactic properties of the substrate language (L1) and a phonological representation derived from the lexifier language, the L2, due to a partially shared semantics. Lefebvre (2008) represents schematically this idea as follows: 


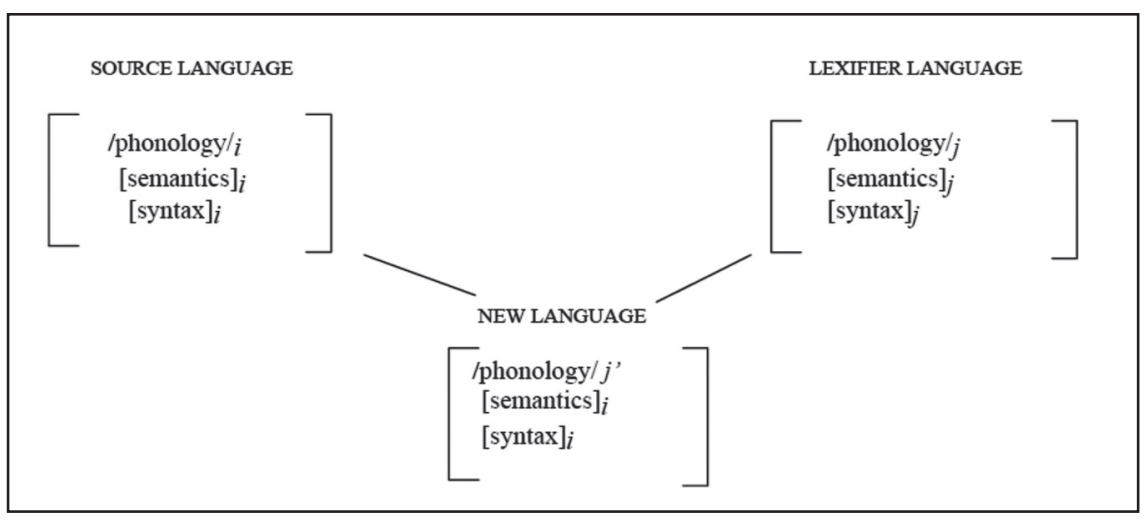

Figure 1: relexification process adapted from Muysken (1981) in Lefebore (2008).

She exemplifies this process with the case of the lexical item HC-/ansansinen/ from her analysis of Haitian Creole. This lexical entry has the semantic properties of /hù/from Fon, the substrate language, meaning in this language "to murder" and "to mutilate" and combines them with the phonological representation close to that of the element which is perceived to share (though partially) some semantics, Fr-/asasine/, in this language meaning "to murder", but not "to mutilate". The new lexical entry resulting from this process is HC-/ansansinen/meaning "to murder" and "to mutilate". Relexification took place in a situation of insufficient access to L2 input "to perceive/learn the properties (categorical/ subcategorization etc.) of the target lexical entries" (Lefebvre 2008).

Sprouse (2006) says that the first phase depicted in the FTFA hypothesis (full transfer) fits exactly in what Lefebvre (1997) defines as a relexification process, saying it is at the core of second language instinct, we can say, just as the search for morphological cues for parameters are in the core of first language instinct. He says:

Full Transfer can be restated in terms of Relexification' and that 'Relexification is at the core of the second language instinct, accounting both for the L2 initial state and for the frequent failure of failure-driven revision to effect convergence on the target language. (Sprouse 2006:170).

This observation has two consequences: it broadens the scope of the notion of relexification, assigning it a more universal scope and reduces the gap between the studies on language contact and second language acquisition by emphasizing the processes common to both linguistic situations.

In the case adressed this paper, nevertheless, relexification, which, according to Sprouse (2006) and the FTFA hypothesis would be a transitional phase in the acquisition process, does not progress towards convergence with the target language, since in most of the subjects tested, IL representation of COS does not 
suffer any change along the development of IL (interlanguage does not seem to grow in this aspect) keeping the same from the initial levels up to its steady state.

This suggests that the predictions of the FTFA hypothesis for some reasons may not apply in some contexts. The context being analyzed here may be one of these. Portuguese and Spanish are typologically related languages and this could be a problem for interlanguage growth in some areas of grammar.

\section{Change of state constructions}

Spanish constructions may be predicative (adjectival passives) or verbal unaccusatives. A study from Correa (2007), based on the online Corpus de Referencia del Español Actual (CREA/RAE) shows that $89 \%$ of the data (2026 tokens from written data) were verbal unaccusatives such as in (3) below and $11 \%$ were predicative, as in example (4) below:

(3) Ana se asusta con los pájaros.

'Ana is scared at the birds.'

(4) Al saberlo me quedé fría.

'When I knew it I got amazed.'

These results confirm the empirical observation that in Spanish systems, in general, these constructions are less frequent and marked, serving to well-defined purposes. According to Miguel and Fernández Lagunilla (2000), work, based on Pustejovsky (1991) semantic decomposition of complex predicates, COS events are understood as complex accomplishments (VENDLER, 1967). Under these assumptions every complex event is conceived in the cognition as a succession of simple events. Accordingly, COS events consist of three phases or sub-events aligned in temporal succession. The initial sub-event where the entity is about to undergo a transition but is associated to the anterior state; the middle one where the transition itself takes place and the final one where the entity is already associated to the resulting state of the change it suffered. And, according to Miguel and Fernández Lagunilla (2000) in a statement, "the speaker can decide to focus in the initial, the middle or the final phase". This could be a simple way of accounting for the differences between adjectival passives and verbal constructions. While verbal constructions focus the change itself, adjectival passives focuses the resulting event.

In the expression of COS by adjectival passives, Spanish present a variety of pseudo-copular verbs each one entailing a different semantic aspect to the construction. According to Porroche Ballesteros (1988), for expressing COS Spanish exhibits ponerse (momentous change) and quedar(se) (it assigns a duration component to the resulting state), as in the examples below (from Porroche Ballesteros 1998, 128): 
(5) ponerse: El cielo se ha puesto negro por un minuto.

'The sky turned black for one minute.'

(6) quedar(se): Después de la tormenta, el cielo se ha quedado azul toda la tarde. 'After the storm the sky kept blue for the whole afternoon'.

For change of quality Spanish exhibits volverse (punctual change) and hacerse (gradual change), as below:

(7) hacerse: En septiembre la situación se hizo ya difícilmente sostenible.

‘By September the situation was already almost untenable.'

(8) volverse: Uno se vuelve, no voy a decir tímido o cobarde frente a ellos, pero sí, precavido.

'One becomes, I will not say timid or cowardly in front of them, but, wary.'

In a semantic-centered approach such as Levin \& Rappaport Hovav (1995) lexical semantic templates, Spanish specifies the possible semantic notions featured in the semantic primitive BECOME and specifies them associating each feature to a different lexical item. As Porroche Ballesteros (1988, p.127) states:

In Spanish there is not a verb corresponding exactly to French devenir, to Italian diventare, to German warden or to English become. Nevertheless Spanish, as most of languages, has a number of procedures (lexical, morphological and syntactic) to express the notion of change ${ }^{2}$.

Some of the resources referred by Porroche are the several pseudo-copular verbs used in Spanish. When it comes to COS predicative constructions, what distinguishes quedar(se) and ponerse is the grammatical aspect associated to each of them. Ponerse constructions do not allow a duration complement:

(9) Ana se puso enferma los tres días que se siguieron a la junta.

2 From the original in Spanish: "En español no existe un verbo que corresponda de un modo exacto al devenir francés, al diventare italiano, al werden alemán o al become inglés. Sin embargo, el español, como la mayor parte de las lenguas, dispone de distintos procedimientos léxicos, morfológicos y sintácticos) para expresar la noción de cambio."

'Ana got sick for three days after the reunion.'

This construction is agrammatical for a permansive reading. It is acceptable only with an iterative reading, since it is interpreted as a punctual COS. Ponerse only shows compatibility with inchoative aspect (next three examples are from BYBEE \& EDDINGTON, 2006):

(10) De repente se pone furiosa porque he mirado dos veces a una persona.

'All of a sudden she gets furious because I looked at someone twice.' 

reading:

Quedar(se), in turn, shows compatibility with a permansive

(11) Se quedó soltera por falta de padre o de hermano.

'She became a spinster for lack of father or brother.'

And allows also an inchoative reading (although there is always a durative aspect that may not be textually expressed):

(12) Al voltearlo con la puntera de la bota para alumbrarle la cara, el capitán se

quedó perplejo.

"Upon turning him over with the tip of his boot in order to shine some light on his face the captain became perplexed."

Accordingly, ponerse is specified for a inchoative reading (alternating with the verbal unaccusative, with the difference that while the former focuses on the resulting state, the latter focuses on the event of change) and quedar(se) carries the feature [+permansive], assigning it to the resulting state in the construction.

\section{Analysis and discussion of interlanguage data}

The results of a study of COS constructions in the interlanguage of Brazilians nonnative speakers of Spanish (CORREA, 2007) show two characteristics of this system: Differently from Spanish COS constructions are predominantly predicative and b) these predicative constructions exhibit a sole pseudo-copular verb, IL-quedar(se) accounting for the meanings of both quedar(se) and ponerse from Spanish.

In a production test, a psycholinguistic questionnaire, subjects ( $n=17)$ had to fill the gaps with the appropriate Spanish version for a Portuguese sentence exhibited to the group in the Data Show. From a total of 24 sentences, 8 were experimental. The results were that $64 \%$ of the subjects filled the forms with predicative quedar(se) constructions, when it was expected that $100 \%$ of the experimental questions were answered as verbal.

This tendency was further corroborated in a recognition test, the experimental group, consisting of another group of Brazilians non-native speakers of Spanish $(n=17)$ should perform a scalar grammaticality judgment, ranging from (-2) (completely unacceptable) to (+2) (totally acceptable). There were 48 sentences and 16 of them were experimental. The result was that most individuals judged as acceptable/totally acceptable sentences that were judged as unacceptable by the ones of the control group, consisting of 9 native speakers of Spanish, from Buenos Aires, Argentina.

Examples below show constructions rejected by the control group and accepted by the experimental group: 
(13) Es muy celosa. Siempre que el móvil de su marido está sin servicio se queda desesperada.

"She is very jealous. She gets desperate whenever her husband's cell phone of out of service.'

(14) Cuando empieza el ruido, la jefa se queda con dolor de cabeza.

"When the noise begins the boss gets a headache."

(15) Cuando hay reunión, Sergio se queda preocupado con todos los asuntos que se discuten.

"When there is a reunion Sergio gets worried about all the subjects discussed."

These constructions were rejected by the control group for not being verbal. Nonetheless their acceptance by Brazilians show that the interlanguage pseudo-copular verb quedar(se) has divergent properties from its Spanish counterpart.

An analysis of the properties and distribution of L1 ficar in Brazilian Portuguese, L1 system of the subjects, shows that this pseudo-copular verb has a wide range, acting as a wild-card verb, since it is compatible in meaning with three out of four Spanish pseudo-copular discussed above (which are not interchangeable between them):

\begin{tabular}{|l|c|l|l|c|}
\hline Pseudo-copular verb & $\begin{array}{l}\text { Punctual } \\
\text { chamge of state }\end{array}$ & $\begin{array}{l}\text { Permansive } \\
\text { chamge of state }\end{array}$ & $\begin{array}{l}\text { Punctual chamge } \\
\text { of property }\end{array}$ & $\begin{array}{l}\text { Gradual chamge } \\
\text { of property }\end{array}$ \\
\hline B portuguese : Ficar & $L$ & $L$ & & $L$ \\
\hline Spanish: Quedar(se) & & $L$ & & \\
\hline Spanish: Ponerse & $L$ & & & \\
\hline Spanish: Hacerse & & & $L$ & \\
\hline Spanish: Volverse & & & & \\
\hline
\end{tabular}

Table 1: comparison of properties of pseudo-copular verbs in Brazilian Portuguese and Spanish

As in the table above, while in Spanish, each of the four pseudo-copular verbs fits in a specific situation, in Brazilian Portuguese the pseudo-copular verb ficar is used to express the same meanings associated to three of their Spanish counterparts, namely, quedar(se), ponerse (change of state) and some cases of volverse (change of property) ${ }^{3}$. In a study comparing the uses of pseudo-copular verbs in Brazilian Portuguese and Spanish, Andrade (2002) analyzed a translation of Colombian writer Gabriel

3 For expressing gradual change of quality Brazilian Portuguese exhibits "virar", as well as for some cases of punctual change of property. García Márquez novel Cien Años de Soledad into Brazilian Portuguese (here indicated as BP). He found correspondences for ficar for each of the four Spanish pseudo-copular verbs discussed, as in the examples below, taken from that study: 
(16) SP.: Cuando despertaron con el sol ya alto, quedaron pasmados de fascinación.

BP: Quando acordaram, já com o sol alto, ficaram pasmos de fascinação.

"When they woke up, the sun high in the sky they got amazed of fascination."

(17) SP.: La vegetación fue cada vez más insidiosa y se hicieron cada vez más lejanos los gritos de los pájaros y la bullaranga de los monos, y el mundo se volvió triste para siempre.

$B P$ : A vegetação se fez cada vez mais insidiosa eficaram cada vez mais longínquos os gritos dos pássaros e a algazarra dos macacos, e o mundo ficou triste para sempre.

"The vegetation became increasingly insidious and the cries of birds and the uproar of the monkeys were far, and the world was sad forever."

(18) Sp: Don Apolinar Moscote se puso pálido.

BP: O senhor Apolinar Moscote ficou pálido.

"Mr. Apolinar Moscote became pale."

Examples show that besides quedar(se), ponerse and volverse (the later in some cases), Andrade (2002) found a case where even hacerse (not easily corresponding to ficar) could be translated to this pseudo-copular verb in Brazilian Portuguese.

Turning back to interlanguage, IL-quedar(se) exhibits properties common to Brazilian Portuguese ficar. Because of this, is not to be confused with L2Spanish quedarse, the reason is that although they have some features in common, IL-quedarse constructions seem to reproduce the aspectual properties and syntactic distribution of BP ficar adjectival passives. It is a hybrid element, corresponding to a merge of semantico-syntactic features from the unique pseudo-copular verb of the receding language/L1 (in this case, $\mathrm{BP}$ ) for expressing COS, and the phonological representation of the pseudo-copular verb bearing the widest distribution in Spanish, quedar(se).

In terms of lexical semantics, it could be said that apparently in vernacular Brazilian Portuguese the semantic primitive BECOME for expressing $\mathrm{COS}^{4}$ has a sole corresponding lexical output, ficar and, differently from Spanish, it is underspecified for the different aspectual notions the different pseudo-copular

4 Observe that we are not talking about the lexical expression of this semantic primitive in cases of change of property. verbs entail in that language.

So, at first sight, this case could fit in the prediction of FTFA which states that at the first stages of interlanguage it corresponds to a transfer of properties from the speaker's L1. But what if in- 
terlanguage doesn't grow? Could we still be talking about FTFA? If it is systematic in several other aspects of this interlanguage grammar this is a more precise situation than the argument of "insufficient input" can account.

We argue that this case can be better understood as a case of relexification. Since data are from steady state interlanguage, they do not show a progress through a full transfer phase towards a full access phase. Instead, they show that the use of a unique wild-card pseudo-copular verb for expressing notions that in Spanish are expressed by two different elements did not change along interlanguage development and the way speakers build COS constructions keeps the same until steady state.

Further evidence comes from other domains of ficar in the L1 that are also domains of IL-quedarse in the interlanguage system. In Spanish, as it was shown, non gradual change of property is often expressed by volverse, another pseudo-copular verb, in this case opposed to hacerse (entailing a gradual change). Even in this case, IL speakers use IL-quedar(se), since this kind of change is also expressed by ficar in the speakers' L1.

Gonçalves (2005) shows that ambiguous input lead to an (unconscious) false feeling that L2 input may be successfully processed by the L1 rules and features - corresponding to IL initial state - in the learner's cognition. The context of typological proximity between L1 ad L2 as in the case of Brazilian Portuguese and Spanish is plenty of ambiguous input due to the apparent similarity between the two systems. The false feeling of being adequately accounting Spanish input could be a real obstacle to a possible reset of interlanguage properties. Instead, the picture could be another one: a relexification process in its own right, where the Spanish lexical item quedarse supplies only its phonological representation to the lexical entry, since the latter exhibits the distribution and selectional properties and the various meanings associated to the supposed corresponding element from the L1. Since there is a permanent false sensation of accounting the L2 input, there is no reason for a parameter/feature value resetting and this becomes a permanent feature of this interlanguage.

\section{Conclusions}

Despite having been exposed to Spanish input for several years, the steady state interlanguage of Spanish speaking Brazilians differs from the target language in several points. Several researchers in Brazil have shown some of these discrepancies, namely: this interlanguage is plenty of null objects (GONZÁLEZ, 1994), there is a preference for participle passives instead of pronominal ones (ARAÚJO JR., 2007) and the means to express change of state differs radically from the target language (COR- 
Some Brazilians non-native speakers of Spanish do show a capability of using adequately the variety of pseudo-copular verbs in Spanish (mostly in written texts, but not only), what apparently seems a convergence with the target language in this aspect. A closer examination, though, suggests that the ways it is obtained are different from native speakers, since it is obtained through a conscious effort and as apparent high processing load. These observations are reflected in the quality of the data, showing characteristics of a incomplete or inconsistent acquisition, such as optionality, indecisions and self-corrections, among others.

6 From the original in Spanish: "El problema de interpretación que se nos presenta a los nativos es el de no saber exactamente cuál es la fase subeventiva que enfoca el hablante de portugués brasileño. El tema crucial, según mi opinión, es que el uso excluyente de quedar(se) en contextos de transición y cambio, nos lleva a interpretarlo con su valor de 'permanencia en un estado', de ahí su falta de aceptabilidad en español."
REA, 2007). These observations lead to a stable characterization of this interlanguage as a particular system.

The observation that Spanish interlanguage of Brazilians present several syntactic characteristics not attested in the target language allows it to be regarded as an autonomous means of communication and the permanence of these characteristics leads to questioning the reach of FTFA. This paper studies a case where the way a content is expressed tends to be always the same, clearly not progressing to surpass the full transfer phase. This may suggest that in some contexts, e.g. typologically close languages such as Portuguese and Spanish some mechanism blocks the possibility of a real acquisition.

Learners seem not to be able to recognize that the several aspectual notions associated to the semantic primitive BECOME should be lexically implemented because there are not previous places for it. Alternatively, this kind of implementation could not be available in adult second language acquisition ${ }^{5}$.

This could be the case, since most of these nonnative speakers - besides preferring to use a predicative construction where it was supposed to be verbal, thus focusing a different sub-event from the one focused in the target language - blur the aspectual subtleties of the events referred, by using a unique relexified pseudo-copular verb in their utterances. This leads to many misunderstandings, as Lieberman (2006) shows, commenting the construction "mi hijo se va a quedar enojado" from a Brazilian student of Spanish in Buenos Aires. She says:

The interpretive problem for us native speakers is that we don't know exactly which sub-eventive phase the Brazilian Portuguese speaker is focusing. In my opinion it is crucial that the exclusive use of quedarse in contexts of transition and change leads us to assign a value of "permanence in a state" to the construction, from which derives its unacceptability in Spanish. ${ }^{6}$

When using IL-quedar(se) (that are understood as marked constructions in the target language), Brazilians inadvertently assign their sentences an extra aspectual element, producing misunderstandings or even unintelligible utterances because lexical entry is a completely new element to Spanish system.

\section{Resumo}

Este artigo analisa o caso de quedar(se), pseudo-cópula típica da interlíngua de brasileiros falantes de espanhol nãonativo. Essa entrada lexical combina propriedades sintáticas e semânticas do seu elemento correspondente em Português Brasileiro, a L1 dos falantes, e a represen- 
tação fonológica da suposta contraparte do Espanhol. Este elemento mantém-se na interlíngua até o seu estágio estável e é analisado aqui como um caso de relexificação (LEFEBVRE 1997), um processo universal presente em várias situações de contato lingüístico, entre elas, Aquisição de Segunda Lingua.

Palavras-Chave: Aquisição de Segunda lingua; Contato Lingüístico; Espanhol, Relexificação.

\section{REFERENCES}

ANDRADE, Otávio G. de. Matizes do verbo português ficar seus equivalentes em espanhol. Londrina: Eduel, 2002.

ARAÚJO JR., Benivaldo. As passivas na produção escrita de brasileiros aprendizes de espanhol como língua estrangeira. M.A. Dissertation, Universidade de São Paulo, 2007.

BYBEE, Joan \& Dave EDDINGTON. A usage based approach to Spanish verbs of "becoming". Language 83.1, 2006.

CORREA, Paulo. A expressão da mudança de estado na interlingua de brasileiros aprendizes de espanhol. Doctoral Dissertation, Universidade Federal do Rio de Janeiro, 2007.

COUTO, Hildo H. do. Hipótese da relexificação na gênese dos crioulos e pidgins. Revista da ABRALIN 1, vol. 1, p. 221-250, 2002. GONÇALVES, Perpétua. Falsos sucessos no processamento do input na aquisição de L2: papel da ambigüidade na gênese do Português de Moçambique. Revista da ABRALIN 4, vol. 1-2, 47-74, 2005.

GONZÁLEZ, Neide. Cadê o pronome? - O gato comeu. Os pronomes pessoais na aquisição/aprendizagem do espanhol por brasileiros adultos. Doctoral Dissertation, Universidade de São Paulo, 1994.

LEFEBVRE, Claire. Relexification in creole genesis: the case of demonstrative terms in Haitian Creole. Journal of pidgins and creole languages 13, 1. p. 93-150, 1997.

. Relabelling: a major process in language contact. Journal of Language Contact - THEMA 2, 2008.

LEVIN, Beth \& Malka RAPPAPORT HOVAV. Unaccusativity an the syntax-lexical semantics interface. Cambridge, Mass.: The MIT Press, 1995.

LIEBERMAN, D. 2006. Efectos de sentido de quedar(se) en la interlengua de brasileños aprendices de español, Ms, Universidad de Buenos Aires, 2006. 
MIGUEL, Elena \& Marina FERNÁNDEZ LAGUNILLA. El operador aspectual se. Revista Española de Lingüística 30, 1. p. 13-43, 2000. MUYSKEN, Peter. Halfway between Quechua and Spanish the case for relexification. In: Valdman, Albert \& Arnold Highfield (eds.). Historicity and variation in creole studies. Ann Arbor: Karoma, p. 52-78, 1981.

PORROCHE BALLESTEROS, Margarita. Ser, estar y verbos de cambio. Madrid: Arco Libros, 1988.

PUSTEJOVSKY, James. The syntax of event structure. In: LEVIN, Beth \& Steven

PINKER. Lexical and conceptual structure. Oxford: Blackwell, 1991. SCHWARTZ \& SPROUSE. Word order and nominative case in nonnative language acquisition: a longitudinal study of (L1 Turkish) German interlanguage. In T. Hoekstra \& B. Schwartz (eds.). Language acquisition studies in generative grammar. Amsterdam: John Benjamins, 1994.

SPROUSE, Rex. Full Transfer and Relexification: Second Language acquisition and creole genesis. In: Claire Lefebvre, Lydia White and Christine Jourdan (eds.). L2 acquisition and creole genesis. Dialogues. Amsterdam and Philadelphia: John Benjamins, 2006.

VENDLER, Zeno. Tense and events. Ms. Cornell University, 1967. 